\title{
TELAAH TERHADAP ESENSI SUBJEK HUKUM: MANUSIA DAN BADAN HUKUM
}

\author{
Dyah Hapsari Prananingrum \\ Staf Pengajar Fakultas Hukum Universitas Kristen Satya Wacana, \\ Korespondensi: dyah.prananingrum@yahoo.com
}

\begin{abstract}
Abstrak
Sebagai pihak yang dapat bertindak dalam hukum, subjek hukum memiliki kewenangan hukum yang tidak dimiliki pihak lain. Ada dua katagori subjek hukum yaitu manusia dan badan hukum. Manusia sebagai subjek hukum yang bersifat natural. Pertanyaan siapakah manusia sehingga dia dapat menjadi subjek hukum, tidak dapat dijawab hanya dengan satu kalimat. Esensi manusia sebagai salah satu dasar menjawabnya. Pertanyaan selanjutnya adalah apakah badan hukum itu sehingga dia dapat berkedudukan sebagai badan hukum. Pertanyaan-pertanyaan inilah yang akan dijawab oleh tulisan ini.
\end{abstract}

Kata-kata Kunci: Subjek Hukum; Manusia; Badan Hukum.

\begin{abstract}
As the parties that are capable to act under the law, legal subject possess particular capacity that is not possessed by other entity. There are two categories of legal subjects, namely human and legal entities. Humans as a legal subject that is natural. However, the question of who is human as the legal subject can not be answered just in one sentence. The analysis of human nature is one way to provide a substantial answer. The next question is what is a legal entity so that it is regarded as a legal subject. These questions will be addressed properly in this paper.
\end{abstract}

Key Words: Legal Subjects; Human; Legal Person. 


\section{PENDAHULUAN}

Istilah subjek hukum di kalangan ahli hukum tidak seragam. Ada yang menggunakan istilah purusa hukum (Oentari Sadino), awak hukum (St. K. Malikul Adil), pribadi hukum (Soerjono Soekanto, Purnadi Purbacaraka) dan sebagainya. ${ }^{1}$ Subjek hukum atau purusa hukum menurut Apeldoorn adalah segala sesuatu yang mempunyai kewenangan hukum atau persoonlijkheid. Kewenangan hukum tersebut merupakan kecakapan untuk menjadi pendukung subjek hukum yang diberikan oleh hukum objektif. ${ }^{2}$ Pengertian subjek hukum atau rechtssubject menurut Algra adalah setiap orang mempunyai hak dan kewajiban, yang menimbulkan wewenang hukum (rechtsbevoegheid). Wewenang hukum adalah kewenangan untuk menjadi subjek dari hak-hak.

Subjek hukum dalam menjalankan perbuatan hukum memiliki wewenang. Wewenang subjek hukum terbagi menjadi dua. Pertama, wewenang untuk mempunyai hak (rechts-bevoegdheid). Kedua, wewenang untuk melakukan (menjalankan) perbuatan hukum dan faktor-faktor yang mempengaruhinya. Subjek hukum menurut Utrecht adalah suatu pendukung hak yaitu manusia atau badan yang menurut hukum berkuasa menjadi pendukung hak. Suatu subjek hukum mempunyai kekuasaan guna mendukung hak atau rechtsvoegdheid. ${ }^{3}$

Menurut Sudikno Mertokusumo, subjek hukum adalah segala sesuatu yang dapat memperoleh hak dan kewajiban dari hukum. ${ }^{4}$ Pendapat senada dikemukakan oleh Subekti yang menyatakan menyatakan bahwa subjek hukum adalah pembawa hak atau subjek dalam hukum, yaitu orang. ${ }^{5}$ Sementara dalam Back's Law Dictionary dirumuskan pengertian subjek hukum sebagai:

One that owes allegience and governed by his law. The natives of Great Britain are subjects of the British Government. Men in free governments are subjects as well as citizens: as they enjoy rights and franhises, as they bound to obey the law. ${ }^{6}$

Istilah subjek hukum berasal dari bahasa Belanda yaitu rechtsubject atau subject of law dalam bahasa Inggris. Secara umum rechtsubject diartikan sebagai pendukung hak dan kewajiban yaitu manusia dan badan hukum. ${ }^{7}$ Dengan demikian subjek hukum adalah segala sesuatu yang memiliki kewenangan hukum, penyandang hak dan kewajiban dalam perbuatan hukum. Subjek hukum sangat terkait dengan kecakapan secara hukum atau rechtsbekwaam, dan kewenangan dalam hukum atau rechtsbevoegd. Subjek hukum (legal subject) adalah setiap pembawa atau penyandang hak dan

Chidir Ali, Badan Hukum (Alumni 2005) 14.

L.J.van Apeldoorn, Pengantar Ilmu Hukum (Pradnya Paramita 1983) 203.

E. Utrecht, Pengantar Dalam Hukum Indonesia (Universitas 1965) 234.

Sudikno Mertokusumo, Mengenal Hukum: Suatu Pengantar(Liberty 1988) 53.

Subekti, Pokok-pokok Hukum Perdata (Pembimbing Masa1996) 19.

Henry Campbell Black, Black's Law Dictionary (West Publishing Co. 2000).

Titik Triwulan Tutik, Hukum Perdata dalam Sistem Hukum Indonesia (Prenada Media 2008) 40. 
kewajiban dalam hubungan-hubungan hukum.

Baik manusia maupun badan hukum semuanya mempunyai kewenangan menyandang hak dan kewajiban, sehingga manusia dan badan hukum disebut mempunyai kewenangan hukum. Namun demikian dalam hal tertentu, kewenangan dalam kaitannya dengan hak-hak yang lahir dari hukum orang dan hukum keluarga hanya dapat dimiliki oleh subjek hukum orang dan tidak disandang oleh subjek hukum badan hukum. Kewenangan hukum yang dimiliki orang perorang, pada kondisi tertentu yang merupakan pengecualian insidentil, seperti keadaan, tempat tinggal, umur, status dan perbuatan seseorang. Hal ini sesuai dengan putusan Mahkamah Agung No. 191/K/Sip/1962 (10 Oktober 1962) yang berpendapat bahwa kemerdekaan seseorang, juga dalam bidang keperdataan, tidak layak diberikan $100 \%$, sebab hal itu bertentangan dengan hukum. ${ }^{8}$

\section{PEMBAHASAN}

\section{Esensi Manusia dan Manusia sebagai Subjek hukum}

Manusia adalah pendukung hak dan kewajiban. Oleh karena itu manusia adalah subjek hukum. Siapakah manusia, sehingga demikian istimewa bila dibandingkan dengan makhluk hidup yang lain, bahkan dinyatakan sebagai subjek hukum saat masih di dalam kandungan, khususnya dalam hukum waris? Realitas manusia pada dasarnya tidaklah cukup disebutkan dalam satu rumusan kalimat. Dari sudut filsafati, manusia dapat disebutkan dalam 3 definisi, yaitu:

a. Definisi klasik menyatakan bahwa manusia adalah hewan berbudi atau animal rationale. Bukan berarti bahwa manusia itu sama dengan hewan yang hanya ditambah dengan budi. Dalam aksi-reaksi biologis ada persamaan, walaupun hanya dalam suatu momen saja dari totalitas atau keseluruhan. Namun dalam aksireaksi psikologis, manusia dengan hewan sama sekali berbeda. ${ }^{9}$

b. Geist-in-welt;

c. Manusia dipandang dari sudut sungguh-sungguh sebagai barang di dunia yang badani, oleh karena memiliki sifat-sifat badani juga;

d. Esprit incarne. Manusia adalah roh yang telah menjelma menjadi daging. Maksudnya bahwa manusia betulbetul bersifat jasmani, stoffelijk. ${ }^{10}$

Dengan demikian, berdasarkan pandangan filsafati manusia di atas, dapat diketahui adanya kesatuan kata dan artinya, bahwa manusia adalah sekaligus jasmani dan rohani. Keistimewaan manusia bila dibandingkan dengan makhluk yang lain adalah akal budi yang dimilikinya. Manusia memiliki, menguasai dan

\footnotetext{
8 Anwar Borahima, Kedudukan Hukum Yayasan di Indonesia, (Disertasi Doktor Universitas Airlangga 2002) 27.

9 A. Sudiarja, Karya Lengkap Driyarkara: Esai-esai Filsafat Pemikiran yang Terlibat Penuh dalam Perjuangan Bangsa (Gramedia Pustaka Utama2006) 146.

$10 \quad$ Ibid. 7.
} 
memastikan dirinya sendiri. Kesadaran tersebut merupakan kesempunaan yang tidak terdapat pada makluk lainnya.

Notohamidjojo, menyatakan bahwa manusia meliputi objek, subjek dan relasi. Manusia sebagai objek adalah manusia dalam perwujudan lahiriah yang memiliki tubuh, mengisi suatu ruang sehingga dapat dicandra. Manusia selain sebagai objek juga mewujudkan subjek yang berarti mempunyai kehendak dan mengambil keputusan yang bebas. Manusia bukanlah subjek yang berdiri sendiri, melainkan senantiasa dalam perhubungan dengan kenyataan. Manusia bukan pula kebebasan saja, namun kebebasan dalam tanggung jawab. Manusia hidup dalam hubungan timbal-balik dengan lingkungannya, dan masyarakatlah lingkungan di mana manusia hidup. Dengan demikian, hakikat manusia dapat dilukiskan sebagai objek-subjekrelasi. ${ }^{11}$

Pada dasarnya setiap manusia atau natuurlijik persoon memiliki kecakapan kecuali undang-undang menyatakan lain. Anak yang masih di bawah umur, orang yang dinyatakan pailit dan orang yang di bawah pengampuan adalah mereka yang tidak memiliki kecakapan untuk melakukan perbuatan hukum. Kewenangan subjek hukum sangat terkait dengan kewenangan yang dimiliki-nya berdasarkan peraturan yang ada. Masalah kecakapan dan kewenangan dalam hukum sangat terkait dengan sah tidaknya perbuatan hukum yang dilakukan subjek hukum tersebut.

Secara yuridis ada beberapa alasan tentang manusia sebagai subjek hukum. Pertama, manusia mempunyai hak-hak subjektif. Kedua, kewenangan hukum yang berarti kecakapan untuk menjadi subjek hukum, yaitu sebagai pendukung hak dan kewajiban. Pada dasarnya manusia mempunyai hak sejak dalam kandungan karena status sebagai subjek hukum yang melekat pada manusia adalah kodrat yang dibawa dari lahir sedangkan hukum hanya mengakuinya saja. Pengecualian atas hak tersebut terdapat di dalam Pasal 2 Kitab Undang-Undang Hukum Perdata (KUH Perdata) yang mengatur bahwa anak yang ada dalam kandungan seorang perempuan dianggap telah lahir, setiap kali kepentingan si anak menghendakinya. Bila telah mati sewaktu dilahirkan, dia dianggap tidak pernah ada. Pengecualian atas hak ini disebut dikenal dengan fiksi hukum. Tidak semua manusia mempunyai kewenangan dan kecakapan untuk melakukan perbuatan hukum, adapun orang yang dapat melakukan perbuatan hukum adalah orang yang cakap menurut hukum. Sedangkan orangorang yang tidak cakap melakukan perbuatan hukum adalah orang yang belum dewasa, orang yang ditaruh di bawah pengampuan, seorang wanita yang bersuami (Pasal 1330 KUH Perdata). 
Dari sudut pandang hukum, menurut Paul Scholten, pengertian manusia adalah orang atau persoon dalam hukum yang mengandung 2 dalil yaitu:

a. Manusia dalam hukum sewajarnya diakui sebagai yang berhak atas hakhak subjektif dan sewajarnya diakui sebagai pihak atau pelaku dalam hukum objektif. Di sini perkataan manusia mempunyai nilai etis. Persoalannya hal ini juga menjadi dasar arti dalil yang ke 2, yaitu:

b. Dalam hukum positif yang merupakan persoon adalah subjek hukum, mempunyai kewenangan. Dalil ini mengandung petunjuk di mana tempat manusia dalam sistem hukum dan dengan demikian dinyatakan suatu kategori hukum. ${ }^{12}$

Menurut Apeldoorn, pengertian orang dalam artian yuridis adalah setiap orang yang mempunyai wewenang hukum. Kewenangan hukum adalah sifat yang diberikan oleh hukum yaitu kecakapan untuk menjadi subjek hukum. Lebih lanjut Apeldoorn berpendapat bahwa hanya manusia yang dapat memiliki hak-hak subjektif, artinya kewenangan dan kewajiban. ${ }^{13}$

Subjek hukum manusia sering juga disebut sebagai subjek kodrati atau purusa kodrat karena pada kodratnya manusia adalah subjek hukum, sehingga sangat berbeda dengan subjek hukum lainnya yang mendapatkan kewenangan hukum dari hukum positif.
Namun pendapat ini tidaklah tepat, karena:

a. Kewenangan hukum bukanlah sifat bawaan manusia, melainkan kualitet yang diberikan oleh hukum positif;

b. Kualitas itu hanya dapat diberikan kepada manusia. Jadi apa yang disebut purusa hukum bukanlah purusa yang sebenarnya. ${ }^{14}$

Hukum Indonesia mengakui setiap manusia sebagai subjek hukum. Hal ini tampak dalam Pasal 1 ayat (1) KUH Perdata yang menyatakan bahwa menikmati hak-hak kewargaan tidak tergantung pada hak-hak kenegaraan. Pengaturan ini mengandung makna bahwa status sebagai warga (yang memiliki makna sebagai subjek hukum) tidak digantungkan pada syarat tertentu yang ditetapkan oleh negara. Pengakuan manusia sebagai subjek hukum tersebut dimulai sejak manusia di dalam kandungan (bila kepentingannya menghendaki demikian), sampai dengan manusia tersebut mati. Pengaturan Pasal 1 KUH Perdata selaras dengan apa yang diatur dalam Pasal 2 dan $3 \mathrm{KUH}$ Perdata. Pasal 2 KUH Perdata menyatakan bahwa anak yang ada dalam kandungan seorang perempuan dianggap telah lahir, setiap kali kepentingan si anak menghendakinya. Bila telah mati sewaktu dilahirkan, dia dianggap tidak pernah ada. Adapun Pasal 3 KUH Perdata menyatakan bahwa tiada suatu hukuman pun yang 
mengakibatkan kematian perdata, atau hilangnya segala hak-hak kewargaan.

Badan Hukum sebagai Subjek Hukum

Selain manusia yang secara kodrati merupakan subjek hukum, hukum juga mengakui eksistensi badan hukum atau rechtspersoon sebagai badan hukum, yang berkedudukan sebagai pendukung hak dan kewajiban. Badan-badan dan perkumpulan-perkumpulan itu dapat memiliki kekayaan sendiri, ikut serta dalam lalu lintas hukum dengan perantaraan pengurusnya, dapat digugat dan menggugat di muka pengadilan. Badan-badan atau perkumpulan tersebut dinamakan Badan Hukum (rechtpersoon) yang berarti orang (persoon) yang diciptakan oleh hukum. ${ }^{15}$ Rechtspersoon biasa disebut sebagai badan hukum yang merupakan persona ficta atau orang yang diciptakan oleh hukum sebagai persona. ${ }^{16}$

Burgelijk Wetboek meng-gunakan istilah rechtpersoon yaitu pada saat diadakannya pengaturan tentang kanak-kanak (kinderwetten). Menurut Pasal 292 Ayat (2) dan Pasal 302 Buku I BW serta sejak diadakannya buku Titel 10 Buku III BW (lama) pada tahun 1838 terdapat banyak ketentuan tentang apa yang dimaksud dengan rechtpersonen tetapi istilah yang digunakan adalah zedelijk lichaam (badan susila). ${ }^{17}$ Mengenai istilah ini, Purnadi
Purbacaraka dan Soerjono Soekanto berpendapat sebagai berikut:

Dalam menejermahkan zadelijk lichaam menjadi badan hukum, lichaam itu benar terjemahannya badan, tetapi hukum sebagai terjemahan zadelijk itu salah, karena arti sebenarnya susila. Oleh karena itu, istilah zadelijk lichaam dewasa ini sinonim dengan rechtpersoon, maka lebih baik kita gunakan pengertian itu dengan terjemahan pribadi hukum. ${ }^{18}$

Dalam peraturan di Indonesia, istilah yang resmi digunakan adalah badan hukum, istilah ini dapat ditemukan dalam peraturan perundangundangan berikut:

a. Undang-Undang Nomor 5 Tahun 1960 tentang Peraturan Pokok Agraria;

b. Peraturan Pemerintah Peng-ganti Undang-Undang Nomor 19 Tahun 1960 tentang Bentuk-Bentuk Usaha Negara;

c. Undang-Undang Nomor 19 Tahun 2003 tentang Badan Usaha Milik Negara;

d. Undang-Undang Nomor 40 Tahun 2007 tentang Perseroan Terbatas, dan sebagainya.

Terjadi banyak perdebatan mengenai bagaimana badan hukum dapat menjadi subjek hukum dan memiliki sifat-sifat subjek hukum seperti manusia. Banyak sekali teori yang ada dan digunakan dunia akademis untuk menjelaskan hal

C.S.T. Kansil, Pengantar Ilmu Hukum (Balai Pustaka 1989) 216.

Sri Soedewi Maschun Sofwan dalam Chidir Ali,Op.Cit. 19.

Ibid. 14. 
tersebut, namun demikian menurut Salim, teori yang paling berpengaruh dalam hukum positif adalah teori konsensi yang pada intinya mengajarkan bahwa badan hukum dalam negara tidak dapat memiliki kepribadian hukum yaitu hak dan kewajiban dan harta kekayaan kecuali di perkenankan oleh hukum dalam hal ini berarti negara sendiri. ${ }^{19}$

Dalam kepustakaan berbahasa Inggris, istilah badan hukum seringkali disebut dengan istilah-istilah: legal entity, juristic person, atau artificial person. Black's Law Dictionary mendefinisikan artificial person sebagai "persons created and devised by human laws for the purposes of society and government, as distinguished from natural person." Sementara legal entity didefinisikan sebagai "an entity, other than natural person, who has sufficient existence in legal contemplation that it can function legally, be sued or sue and make decisions through agents as in the case of corporation." ${ }^{20}$ Lebih lanjut Black's Law Dictionary, memberikan pengertian legal entity sebagai: "(a) body, other than a natural person, that can function legally, sue or be sued, and make decisions thorugh agents." ${ }^{21}$ Sedangkan legal person diartikan sebagai "an entity such as corporation, created by law given certain legal rights and duties of a human being; a being, real or imaginary, who for the purpose of legal reasoning is treated more or less as a human being." 22
Berdasarkan Pasal 1654 KUH Perdata, badan hukum didefinisikan sebagai semua perkumpulan yang sah adalah seperti halnya dengan orangorang preman, berkuasa melakukan tindakan-tindakan perdata, dengan tidak mengurangi peraturan-peraturan umum, dalam mana kekuasaan itu telah diubah, dibatasi atau ditundukkan pada acara-acara tertentu. Sebelumnya dalam Pasal 1653 KUH Perdata diatur berkaitan dengan perkumpulan adalah selainnya perseroan yang sejati oleh undang-undang diakui pula perhimpunan orang sebagai perkumpulan, baik yang diadakan atau diakui sebagai demikian oleh kekuasaan umum, maupun yang diterima sebagai diperbolehkan, atau telah didirikan untuk suatu maksud tertentu yang tidak bertentangan dengan undang-undang atau kesusilaan. Dengan demikian berdasarkan Pasal 1653 Bab Kesembilan dari Buku Ketiga KUH Perdata, ada 3 macam perkumpulan yaitu:

a. Perkumpulan yang diadakan oleh kekuasaan umum;

b. Perkumpulan yang diakui oleh kekuasaan umum;

c. Perkumpulan yang diperkenankan atau untuk suatu maksud tertentu tidak berlawanan dengan undangundang atau kesusilaan.

Pasal 1653 KUH Perdata tersebut merupakan landasan yuridis keberadaan badan hukum baik badan

18 Purnadi Purbacarakadalam Chidir Ali, Ibid. 17.

19 Salim H.S., Pengantar Hukum Perdata Tertulis (BW) (Sinar Grafika2005).

$20 \quad$ Henry Campbell Black, Op.Cit. 726.

21 Bryan A. Garner, Black's Law Distionary (West Publishing Co. 2009) 976.

22 Ibid. 1178. 
hukum publik maupun privat, meskipun tidak secara tegas mengaturnya.

Pada umumnya, ahli hukum tidak sependapat dengan menempatkan pengaturan badan hukum di dalam Buku III KUH Perdata. Badan hukum yang pada dasarnya merupakan subjek hukum tidak tepat dimasukkan dalam hukum perikatan, walau sebagian dari badan hukum tersebut lahir dari perjanjian. Namun demikian tidak tepat pula bila badan hukum yang merupakan subjek hukum diatur bersama-sama dengan subjek hukum manusia. Badan hukum merupakan persoon karena hukum dan struktur badan hukum yang menopang eksistensi badan hukum adalah struktur hukum, berbeda dengan manusia yang struktur manusia sama sekali bukan persoalan hukum.

Berikut adalah beberapa pendapat tentang pengertian badan hukum. Menurut Apeldoorn, yang dimaksud dengan purusa hukum (badan hukum) adalah:

a. Tiap-tiap persekutuan manusia, yang bertindak dalam pergaulan hukum seolah-olah ia suatu purusa yang tunggal;

b. Tiap-tiap harta dengan tujuan yang tertentu, tetapi dengan tiada yang empunya, dalam pergaulan hukum diperlakukan seolah-olah ia sesuatu purusa (yayasan). ${ }^{23}$
Menurut Utrecht, badan hukum merupakan setiap pendukung hak yang tidak berjiwa atau bukan manusia. ${ }^{24}$ Menurut Sudikno Mertokusumo, badan hukum adalah organisasi atau kelompok manusia yang mempunyai tujuan tertentu yang dapat menyandang hak dan kewajiban. ${ }^{25}$ Menurut Subekti badan hukum adalah suatu badan atau perkumpulan yang dapat memiliki hakhak melakukan perbuatan seperti seorang manusia, serta memiliki kekayaan sendiri yang dapat digugat atau menggugat di depan hakim. ${ }^{26}$

Dengan demikian rechts-persoon atau badan hukum adalah orang yang diciptakan oleh hukum dan mampu melakukan perbuatan-perbuatan hukum yang memiliki kekayaan sendiri. Pengertian mengenai badan hukum yang lebih lengkap dapat ditemukan dari pendapat Molengraaff. Badan hukum menurut Molengraaff merupakan hak dan kewajiban dari para anggotanya secara bersama-sama, dan didalamnya terdapat harta kekayaan bersama yang tidak dapat dibagi-bagi. Setiap anggota tidak hanya menjadi pemilik sebagai pribadi untuk masing-masing bagiannya dalam satu kesatuan yang tidak dapat dibagi-bagi itu, tetapi juga sebagai pemilik bersama untuk keseluruhan harta kekayaan, sehingga setiap pribadi anggota adalah juga pemilik harta kekayaan yang terorganisasikan dalam badan hukum itu. ${ }^{27}$

\footnotetext{
L.J. van Apeldoorn, Op.Cit. 205.

E. Utrecht, Op.Cit. 236.

Sudikno Mertokusumo, Op.Cit. 53.

Subekti, Op.Cit. 48.

27 Jimly Asshiddiqie, Perkembangan dan Konsolidasi Lembaga Negara Pasca Reformasi (Sekjen dan Kepaniteraan MKRI2006) 69.
} 
Oentarid Sadino menterjemahkan buku L.J. van Apeldoorn yang berjudul Inleiding tot de Studie van het Nederlandse Recht (Pengantar Ilmu Hukum) tentang masalah subjek hukum menerjemahkannya dalam bahasa Indonesia sebagai berikut:

Walaupun demikian, ajaran hukum dan kini juga undang-undang mengakui adanya purusa atau subjek hukum yang lain dari manusia. Untuk membedakannya, manusia disebut purusa kodrat (natuurlijke personen) yang lain purusa hukum. Akan tetapi ini tidak berarti, bahwa purusa yang demikian itu juga benar-benar terdapat. Itu hanya berarti, bahwa sesuatu yang bukan purusa atau tidak dapat merupakan purusa, diperlaku-kan seolah-olah ia adalah suatu purusa.

Istilah purusa kodrat dan purusa hukum bersandar pada pandangan (yang berasal dari ajaran hukum kodrat) bahwa menurut kodratnya manusia adalah subjek hukum dan yang lainlainnya memperoleh kewenangan hukumnya dari hukum positif... ${ }^{28}$

Menurut Logemann, badan hukum adalah suatu personifikasi atau bestendigheid (perwujudan, penjelmaan), hak-kewajiban hukum organisasi (orgnisatie recht) yang menentukan struktur internal (inneelijkstruktuur) dari personifikasi itu. $^{29}$
Menurut Rochmat Soemitro, badan hukum atau rechtspersoon adalah suatu badan atau perkumpulan yang dapat mem-punyai harta, hak, serta kewajiban seperti orang-orang pribadi. ${ }^{30}$ Wirjono Prodjodikoro menyatakan badan hukum sebagai badan di samping manusia perseorangan yang dianggap dapat bertindak dalam hukum dan yang mempunyai hak-hak, kewajiban-kewajiban dan hubungan hukum dengan orang lain maupun badan lain. ${ }^{31}$

Sri Soedewi Maschun Sofwan mengartikan badan hukum sebagai kumpulan dari orang-orang yang bersama-sama mendirikan suatu badan (per-himpunan) dan kumpulan harta kekayaan yang ditersendirikan untuk tujuan tertentu. Kedua-duanya merupakan badan hukum. ${ }^{32}$ Tidak terlalu jauh berbeda dengan pendapat Sri Soedewi tersebut di atas, adalah pendapat yang dikemukakan oleh J.J. Dormeiner yang membagi 2 pengertian badan hukum, yaitu:

a. Persekutuan orang-orang, yang di dalam pergaulan hukum bertindak selaku seorang saja; dan

b. Yayasan, yaitu suatu harta atau kekayaan yang dipergunakan untuk suatu maksud yang tertentu.

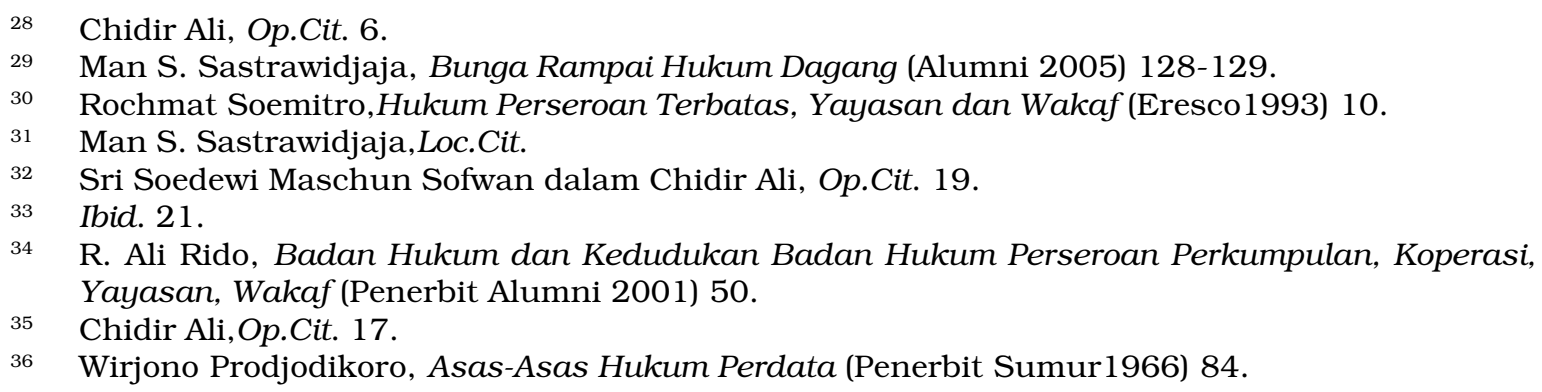


Yayasan itu digunakan sebagai oknum. ${ }^{37}$

Berdasarkan pendapat-pendapat para ahli hukum mengenai badan hukum di atas dapat diketahui bahwa tidak ada keraguan sedikitpun mengenai kedudukan badan hukum sebagai subjek hukum, karena badan hukum merupakan lembaga yang independen, penyandang hak dan kewajiban, serta dapat bertindak di depan hukum. Implikasi hukum dari independen atau kemandirian tersebut, bahwa keberadaan badan hukum tersebut tidak digantungkan pada kehendak pendiri atau organ namun ditentukan oleh hukum. Dalam pengertian pokok, apa badan hukum itu adalah segala sesuatu yang berdasarkan tuntutan kebutuhan masyarakat yang demikian itu oleh hukum diakui sebagai pendukung hak dan kewajiban.

Dalam badan hukum terdapat 2 (dua) unsur penting yang harus diperhatikan. Pertama, dapat dipisahkannya hak dan kewajiban badan hukum dari hak dan kewajiban anggota badan hukum. Kedua, organ badan hukum dapat berganti-ganti namun demikian badan hukum tetap ada. Dengan demikian badan hukum merupakan penyandang hak dan kewajibannya sendiri sebagai subjek hukum yang memiliki status yang dipersamakan dengan orang perorangan sebagai subjek hukum. Sebagai implikasinya, badan hukum dapat digugat maupun menggugat di pengadilan. Kondisi ini membawa konsekuensi bahwa keberadaan dan ketidak-beradaannya sebagai badan hukum tidak bergantung pada kehendak sendiri atau anggotanya melainkan ditentukan oleh hukum.

Berdasarkan pendapat dari para ahli tentang kriteria badan hukum yang telah dipaparkan di atas, maka dapat disusunlah unsur-unsur badan hukum adalah sebagai berikut:

a. Adanya pemisahan harta kekayaan antara pendiri dengan badan hukum;

b. Mempunyai harta kekayaan tertentu;

c. Memiliki kepentingan tertentu;

d. Memiliki organ yang menjalankan badan hukum;

e. Adanya managemen yang teratur.

Unsur-unsur inilah yang dapat ditemukan dalam suatu badan hukum, serta dapat digunakan untuk membedakan badan hukum dengan bukan badan hukum.

Ajaran para ahli hukum berkaitan dengan badan hukum dapat dipaparkan sebagai berikut. Menurut Scholten badan hukum haruslah memenuhi unsur-unsur:

a. Mempunyai harta kekayaan sendiri, yang berasal dari suatu perbuatan hukum pemisahan;

b. Mempunyai tujuan tertentu sendiri;

c. Mempunyai alat perlengkapan atau organisasi.

37 Nindyo Pramono, Persembahan Kepada Sang Maha Guru, Seputar Hukum Bisnis (FH-UGM 2007) 114. 
Menurut Ali Rido, untuk menentukan kriteria sebagai badan hukum, doktrin memberikan syarat sebagai berikut:
a. Adanya harta kekayaan yang terpisah;
b. Mempunyai tujuan tertentu;
c. Mempunyai kepentingan;
d. Adanya organisasi yang teratur. ${ }^{38}$

Sedangkan menurut Soenawar Soekowati, badan hukum harus memenuhi unsur-unsur:

a. Ada harta kekayaan yang terpisah, lepas dari kekayaan anggotaanggotanya (penulis: pendiri);

b. Adanya kepentingan yang diakui dan dilindungi oleh hukum, serta bukan kepentingan satu atau beberapa orang saja;

c. Kepentingan tersebut haruslah panjang (stabil);

d. Harus dapat ditunjukkan suatu harta kekayaan yang tersendiri, yang tidak saja untuk objek tuntutan tetapi juga sebagai upaya pemeliharaan kepentingankepentingan badan hukum yang terpisah dari kepentingan angggotaanggotanya (penulis: pendiri). ${ }^{39}$

Wirjono Projodikoro, menjelaskan kriteria atau ukuran untuk menjelaskan badan hukum adalah: a. Adanya benda kekayaan yang terpisah dari orang perseorangan yang bertindak;

b. Adanya kepentingan yang bukan kepentingan orang perseorangan, melainkan kepentingan suatu golongan orang-orang, dan

c. Bersifat atau memiliki tujuan untuk berdiri dalam waktu yang lama. ${ }^{40}$

Menurut Nindyo Pramono, unsur yang terdapat dalam badan hukum adalah kehendak dan kedudukan yang mandiri (persona standi in judicio), serta kekayaan yang terpisah dari badan hukum. ${ }^{41}$

Berdasarkan pendapat dari para ahli tersebut di atas dapat disimpulkan, bahwa pemisahan harta kekayaan antara kekayaan pendiri dan kekayaan badan hukumnya menjadi salah satu persyaratan yang mutlak ditemukan dalam suatu badan hukum. Kekayaan badan hukum inilah yang digunakan oleh badan hukum untuk memenuhi tanggung jawabnya sebagai subjek hukum. Syarat lain yang menjadi perhatian para ahli yaitu adanya tujuan tertentu yang dimiliki oleh badan hukum. Tujuan inilah yang menjadi alasan badan hukum didirikan dan terus eksis, dan bila tujuan dari badan hukum telah tercapai maka berakhirlah badan hukum tersebut. Syarat organisasi menjadi satu syarat yang tidak kalah penting bila dibandingkan dengan badan hukum yang lain. Di dalam organisasi

\footnotetext{
Jimly Asshiddiqie, Op.Cit. 71.

E. Utrecht, Op.Cit. 237-238.

L.J. van Apeldoorn, Op.Cit. 206.

Sri Soedewi Masjchun Sofwan dalam Anwar Borahima, Op.Cit. 45.
} 
akan dapat ditemukan organ badan hukum, pembukuan walaupun mungkin sangat sederhana, dan kesinambungan dalam beraktivitas. Dengan demikian walaupun badan hukum hanya didirikan oleh satu orang saja dalam badan hukum akan ditemukan organisasi walaupun sangat sederhana.

Setiap badan hukum yang dapat dikatakan mampu bertanggungjawab (recht-bevoegheid) secara hukum, harus memiliki empat unsur pokok, yaitu:

a. Harta kekayaan yang terpisah dari kekayaan subjek hukum yang lain;

b. Mempunyai tujuan ideal tertentu yang tidak bertentangan dengan peraturan perundang-undangan;

c. Mempunyai kepentingan sendiri dalam lalu lintas hukum;

d. Ada organisasi kepengurusannya yang bersifat teratur menurut peraturan perundang-undangan yang berlaku dan peraturan internalnya sendiri. ${ }^{42}$

Sebagaimana layaknya subjek hukum, badan hukum mempunyai kewenangan melakukan perbuatan hukum seperti halnya orang, akan tetapi perbuatan hukum itu hanya terbatas pada bidang hukum harta kekayaan. Mengingat wujudnya adalah badan atau lembaga, maka dalam mekanisme pelaksanaannya badan hukum bertindak dengan perantara penguruspengurusnya.

Sebagai subjek hukum yang berkedudukan sebagai pendukung hak dan kewajiban, badan hukum diakui eksistensinya. Berdasarkan Pasal 1653 KUH Perdata, terdapat 4 jenis badan hukum yaitu:

a. Badan hukum yang didirikan oleh Pemerintah. Termasuk dalam kategori badan hukum ini adalah badan hukum publik seperti provinsi, kabupaten, kota dan lain sebagainya;

b. Badan hukum yang diakui oleh Pemerintah, misalnya gereja atau badan keagamaan lainnya;

c. Badan hukum yang diijinkan oleh Pemerintah;

d. Badan hukum yang didirikan oleh pihak swasta atau partikelir.

Namun demikian, dari beberapa pendapat ahli dapat dikemukakan jenisjenis badan hukum yang berbeda satu dengan yang lain. Utrecht menyatakan bahwa dalam pergaulan hukum terdapat bermacam-macam badan hukum, yaitu:

a. Perhimpunan yang dibentuk dengan sengaja dan sukarela oleh orang yang bermaksud memperkuat kedudukan ekonomis mereka, memelihara kebudayaan, mengurus soal-soal sosial dan sebagainya;

b. Persekutuan orang yang ada kerena perkembangan faktor-faktor sosial dan politik dalam sejarah. Termasuk dalam badan hukum ini adalah negara, provinsi, kabupaten, dan desa;

c. Organisasi yang didirikan berdasarkan undang-undang, tetapi 
bukan perhimpunan yang termasuk dalam huruf a;

d. Yayasan. ${ }^{43}$

Apeldoorn membagi badan hukum menjadi 3 jenis, sebagai berikut:

a. Perhimpunan yaitu persekutuanpersekutuan yang hidupnya timbul dari penggabungan secara sukarela dari purusa-purusa pribadi yang berdasarkan perjanjian dan bertindak seolah-olah adalah suatu purusa;

b. Persekutuan yang tidak didirikan oleh purusa-purusa khususnya, melainkan tumbuh secara historis, seperti negara, propinsi dan sebagainya;

c. Persekutuan yang didirikan oleh kekuasaan umum seperti waterschappen. ${ }^{44}$

Sri Soedewi Masjchun Sofwan membagi badan hukum menjadi 2 bagian. Pertama, badan hukum ketatanegaraan yang meliputi: (1) Daerah otonom, sebagai contoh: Propinsi, Kabupaten; (2) Lembaga-lembaga, Majelis, Bank-bank. Kedua, badan hukum keperdataan yang meliputi: (1) Zadelijk lichaam; (2) Yayasan; (3) Badan-badan hukum yang termasuk dalam hukum dagang. ${ }^{45}$

Secara sederhana pembagian badan hukum, dikemukakan oleh Chidir Ali, yang membagi badan hukum menjadi 2 bagian menurut golongan hukum yaitu golongan hukum publik dan golongan hukum privat. ${ }^{46}$ Menurut sementara ahli hukum, badan hukum yang didirikan oleh penguasa (negara), merupakan badan hukum publik dan mempunyai wewenang publik. Pendapat ini didasarkan pada ketentuan Pasal 1653 KUH Perdata menyatakan bahwa badan hukum yang didirikan dengan undangundang. Pendapat ini mendapatkan tentangan dari Soenawar Soekowati yang beranggapan bahwa tidak semua badan hukum yang didirikan berdasarkan hukum publik tersebut merupakan badan hukum publik serta memiliki wewenang publik dan berkebalikan dengan hal itu maka masuk kategori badan hukum privat. Badan hukum yang didirikan dengan mendasarkan pada hukum privat, pada stelsel hukum tertentu, badan tersebut miliki kewenangan publik.

Menurut Chidir Ali kriteria suatu badan hukum dapat dinyatakan sebagai badan hukum publik adalah sebagai berikut:

a. Dilihat dari cara pendiriannya yang didirikan berdasarkan konstruksi hukum publik, yaitu didirikan oleh penguasa (negara) dengan undangundang atau peraturan-peraturan lainnya;

b. Lingkungan kerjanya, apakah dalam melaksanakan tugasnya umumnya dengan publik/umum dengan tidak melakukan perbuatan-perbuatan hukum perdata pada umumnya

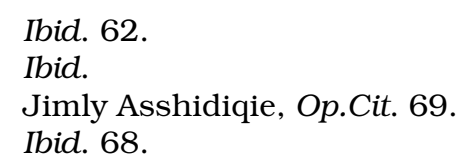


seperti halnya badan-badan hukum privat;

c. Kewenangan yang dimiliki, bahwa badan hukum publik memiliki kewenangan untuk membuat keputusan, ketetapan atau peraturan yang mengikat umum. ${ }^{47}$

Adapun macam badan hukum publik ini dapat dilihat dari badan hukum publik yang memiliki teritorial dan badan hukum publik yang tidak memiliki teritorial. Dua macam badan hukum publik tersebut selanjutnya dapat dijelaskan sebagai berikut. Pertama, badan hukum yang mempunyai teritorial. Suatu badan hukum itu pada umumnya harus memperhatikan atau menyelenggarakan kepentingan mereka yang tinggal di dalam daerah atau wilayahnya. Kedua, badan hukum yang tidak mempunyai teritorial. Suatu badan hukum yang dibentuk oleh yang berwajib hanya untuk tujuan tertentu saja.

Adapun badan hukum perdata merupakan badan hukum yang didirikan atas pernyataan kehendak dari orang-perorangan. Badan hukum publik dimungkin-kan mendirikan badan hukum perdata seperti yayasan, Perseroan Terbatas dan lain sebagainya. Badan hukum perdata yang diatur dalam peraturan perundang-undangan yang dapat disebutkan di bawah ini:

a. perkumpulan (vereniging), diatur dalam Pasal 1653 KUHPerdata, Stb. 1870-64, dan Stb. 1939-570; b. Perseroan Terbatas, diatur dalam UU No. 40 tahun 2007;

c. rederji, diatur dalam Pasal 323 Kitab Undang-Undang Hukum Dagang (KUH Dagang);

d. kerkgenootschappen, diatur dalam Stb. 1927-156;

e. koperasi, diatur dalam UndangUndang Nomor 5 Tahun 1992 tentang Perkoperasian;

f. yayasan, dan lain-lain.

Selanjutnya untuk membedakan antara badan hukum publik dengan badan hukum privat atau perdata sebagaimana telah dipaparkan di atas, dapat dengan memperhatikan hal-hal berikut di bawah ini:

a. Pembedaan badan hukum publik dan privat tersebut dapat dilihat melalui prosedur pendiriannya, artinya badan hukum publik itu diadakan dengan konstruksi hukum publik yaitu didirikan oleh penguasa dengan undang-undang atau peraturan-peraturan lainnya. Perbedaan tersebut terletak pada bagaimana cara pendiriannya badan hukum tersebut, seperti yang diatur di dalam Pasal 1653 KUHPerdata yaitu ada tiga macam, yakni:

- badan hukum yang diadakan oleh kekuasaan umum (Pemerintah atau Negara).

- badan hukum yang diakui oleh kekuasaan umum.

- badan hukum yang diperkenankan dan yang

$47 \quad$ Chidir Ali, Op.Cit. 33. 
didirikan dengan tujuan tertentu yang tidak bertentangan dengan undang-undang atau kesusilaan (badan hukum dengan konstruksi keperdataan).

b. Pembedaan badan hukum privat dengan badan hukum publik dapat dilihat dari siapa pendiri dari badan hukum tersebut. Badan hukum perdata adalah badan hukum yang didirikan oleh perseorangan, sedangkan pada badan hukum publik ialah badan hukum yang diadakan oleh kekuasaan umum.

c. Perbedaan dengan melihat lingkungan kerjanya, yaitu apakah dalam melaksanakan tugasnya badan hukum itu pada umumnya dengan publik atau melakukan perbuatan-perbuatan hukum perdata.

d. Mengenai wewenangnya, yaitu apakah badan hukum yang didirikan oleh penguasa itu diberi wewenang untuk membuat keputusan, ketetapan atau peraturan yang mengikat umum. Jika ada wewenang publik, maka ia adalah badan hukum publik.

Secara alamiah, badan hukum tidak dapat berkedudukan sebagai subjek hukum. Hal ini dikarenakan badan hukum tidak memiliki kehendak, tidak dapat bertindak dan tidak dapat hadir atau ada seperti halnya karak-teristik yang dapat ditemukan pada orang seperti yang telah dikemukakan di atas. Karakteristik tersebut yang mengakibatkan orang dapat berkedudukan sebagai subjek hukum secara kodrati. Ketiadaan karak-teristik tersebut berimplikasi bahwa badan hukum tidak dapat menjalankan fungsinya sebagai subjek hukum. Problematika yang dihadapi oleh badan hukum tersebut yang pada akhirnya menghadirkan teori-teori badan hukum. Teori-teori badan hukum yang berkembang adalah sebagai berikut. ${ }^{48}$

a. Teori Fiksi, teori ini dikemukakan oleh Frederich Carl von Savigny pada permulaan abad 19. Teori ini menyatakan bahwa badan hukum adalah suatu abstraksi, bukan merupakan sesuatu yang konkrit. Hukum memberikan kepada subjek hukum hak-hak suatu kekuasaan dan menimbulkan kehendak berkuasa (wilsmacht). Adapun badan hukum hanyalah buatan negara yang sebenarnya tidak ada tetapi orang menghidupkannya dalam bayangannya untuk menerangkan sesuatu hal. Adapun yang menjadi wakil-wakil dalam melakukan perbuatan adalah manusia yang ada dalam badan hukum tersebut. Oleh sebab itu teori ini dikenal sebagai teori fiksi.

b. Teori Organ, teori ini dikemukakan oleh Otto von Gierke (1841-1921). Badan hukum itu seperti manusia, menjadi penjelmaan yang benarbenar dalam pergaulan hukum. Teori organ memandang badan hukum sebagai suatu yang nyata (reliteit) bukan fiksi, pandangan ini diikuti oleh L.C. Polano. Menurut 
teori organ badan hukum merupakan een bestaan, dat hun realiteit dari konstruksi yuridis seolah-olah sebagai manusia yang sesungguhnya dalam lalu lintas hukum yang juga mempunyai kehendak sendiri yang dibentuk melalui alat-alat kelengkapannya yaitu pengurus dan anggotanya dan sebagainya. ${ }^{45}$ Putusan yang dibuat oleh pengurus adalah kemauan badan hukum. Badan hukum itu menjadi suatu badan yang membentuk kehendaknya dengan perantaraan alat-alat atau organorgan yang terdapat dalam badan tersebut, misalnya anggota atau pengurus badan hukum tersebut. Apa yang diputuskan dan dilakukan oleh organ adalah kehendak dari badan hukum. Dengan demikian berdasarkan teori organ, badan hukum adalah sesuatu yang riil, benar-benar ada.

c. Teori kekayaan bertujuan, destinataristheorie atau leer van het doelvermogen yang diajarkan oleh A. Brinz dan F.J. van Heyden. Teori harta kekayaan bertujuan oleh A. Brinz dalam bukunya Lehrbuch der Pandecten (1883) dinyatakan bahwa:

Only human beings can be considered correctly as 'person'. The law, however, protects purpose other than those concerning the interest of human beings. The property 'owned' by corporations does not 'belong' to anybody. But it may considered as belonging for certain purposes and the device of the corporation is used to protect those purpose. ${ }^{49}$
Badan hukum menurut teori kekayaan bertujuan bukanlah terdiri dari anggota-anggota yang merupakan subjek hukum, namun badan hukum ini terdiri atas harta kekayaan tertentu yang terlepas dari yang memegangnya atau onpersoonlijk. Sehingga dapat dijelaskan teori harta kekayaan bertujuan ini melihat bahwa pemisahan kekayaan badan hukum dengan kekayaan anggotanya dimaksudkan untuk mencapai suatu tujuan tertentu. Harta kekayaan ini menjadi milik dari perkumpulan yang bersangkutan, yang menyebabkan perkumpulan ini menjadi subjek hukum. Implementasi tentang teori pemisahan harta kekayaan dalam badan hukum ini dasarnya terdapat dalam pasal 1618, 1640, $1641 \mathrm{KUH}$ Perdata.

d. Teori tentang harta kekayaan yang dimiliki oleh seseorang dalam jabatannya atau Leer van het ambtelijk vermogen. Teori ini mengajarkan tentang harta kekayaan yang dimiliki seseorang dalam jabatannya (ambtelijk vermogen) yaitu suatu hak yang melekat pada suatu kualitas. ${ }^{50}$ Teori zweck vermogen ataupun doel vermogens theorie mengembangkan pendapat bahwa badan hukum merupakan badan yang mempunyai hak atas harta kekayaan tertentu yang dibentuk untuk tujuan melayani kepentingan 
tertentu. Adanya tujuan tersebut menentukan bahwa harta kekayaan dimaksud sah untuk diorganisasikan menjadi ba-dan hukum. Teori ini menitik beratkan pada daya berkehendak (wilsvermogen) dari suatu subjek hukum. Adapun dalam badan hukum, yang berkehendak ialah pengurus dari badan hukum yang bersangkutan. Dalam kualitasnya sebagai pengurus mereka adalah berhak, maka dari itu disebut ambtelijk vermogen.

Dengan bertitik tolak dari pemikiran bahwa manusia sajalah yang dapat menjadi subjek hukum, maka badan hukum bukanlah sunyek hukum. Adapun hak-hak yang diberikan kepada subjek hukum pada hakikatnya adalah hak-hak dengan tiada subjek hukum namun merupakan kekayaan yang terikat oleh suatu tujuan atau kekayaan yan dimiliki oleh tujuan itu. ${ }^{48}$

e. Teori Kekayaan Bersama, dikemukakan oleh Rudolf von Jhering pada tahun 1818-1892. Pengikut dari teori ini adalah Marcel Planiol (Perancis), Molengraaff (Belanda), Star Busmann, Kranenburg, Paul Scholten dan Apeldoorn. Teori kekayaan bersama ini menganggap badan hukum sebagai kumpulan manusia. Kepentingan badan hukum adalah kepentingan seluruh anggotanya. ${ }^{51}$ Dengan demikian badan hukum berdasarkan Teori Kekayaan
Bersama ini adalah suatu konstruksi yuridis dari kepentingankepentingan anggota, dengan demikian hak dan kewajiban badan hukum adalah hak dan kewajiban serta tanggung jawab hukum dari anggota secara bersama-sama. Konsekuensi yuridisnya bahwa harta kekayaan badan hukum adalah milik bersama seluruh anggota.

f. Teori Kenyataan Yuridis atau Juridische Realiteitsleer, dikemukakan oleh E.M. Meijers dan dianut oleh Paul Scholten. Teori ini menyatakan bahwa badan hukum merupakan suatu realitas, konkret, riil walaupun tidak dapat diraba dan merupakan kenyataan yuridis. Dengan demikian Meijers ingin mempersamakan badan hukum dengan manusia hanya sebatas pada bidang hukum saja. Dalam kenyataan yuridis, badan hukum adalah wujud riil, sama riilnya dengan manusia. Badan hukum adalah persoon dalam artian subjek hak saja. Menurut teori ini, badan hukum merupakan kelompok yang kegiatan dan aktivitasnya diakui hukum (seperate legal recognition) dari kegiatan dan aktivitas individu kelompok yang terlibat dalam badan hukum. ${ }^{50}$ Mengenai bertindaknya badan hukum ini dilakukan dengan per-antaraan orang. Ciri yang ditemukan dalam badan hukum berdasarkan teori ini adalah:

$51 \quad$ Ibid. 56 
a. Memiliki kepribadian hukum atau personalitas hukum (legal personality) yang berbeda dan terpisah (distinct and separate) dari kepribadian hukum individu personnya;

b. Hukum memperbolehkan penerapan tanggung jawab terbatas (limited liability) hanya sebatas harta kekayaan badan hukum, serta dalam hal melakukan gugatan ataupun digugat atas nama badan hukum;

c. Memiliki pengurus yang bertindak mengurusi kegiatan (management) badan hukum, serta mewakili (representative) badan hukum di muka hukum. ${ }^{51}$

\section{PENUTUP}

Subjek hukum yang memiliki kewenangan dan mampu bertindak melakukan perbuatan-perbuatan hukum, terdiri dari manusia dan badan hukum. Esensi manusia menjadikan manusia sebagai subjek hukum kodrati. Sedangkan badan hukum yang nota bene adalah subjek hukum yang diberikan oleh negara, memiliki batasan dan syarat-syarat tertentu dalam menjalankan kewengannya sebagai subjek hukum.

\section{DAFTAR BACAAN}

Ali, Chidir, Badan Hukum (Alumni 2005).

Apeldoorn, L.J.van, Pengantar Ilmu Hukum (Pradnya Paramita 1983).
Asshiddiqie, Jimly, Perkembangan dan Konsolidasi Lembaga Negara Pasca Reformasi (Sekjen dan Kepaniteraan MKRI 2006).

Black, Henry Campbell, Black's Law Dictionary (West Publishing Co. 2000).

Borahima, Anwar, Kedudukan Hukum Yayasan di Indonesia, (Disertasi Doktor Universitas Airlangga 2002).

Chatamarrasdjid, Badan Hukum Yayasan (Citra Aditya Bakti 2002).

Garner, Bryan A., Black's Law Distionary (West Publishing Co. 2009).

Harahap, M. Yahya, Hukum Perseroan Terbatas (Sinar Grafika 2009).

Kansil, C.S.T., Pengantar Ilmu Hukum (Balai Pustaka 1989).

Mertokusumo, Sudikno, Mengenal Hukum: Suatu Pengantar (Liberty 1988).

Notohamidjojo, O., Demi Keadilan dan Kemanusiaan (BPK Gunung Mulia 1973).

Pramono, Nindyo, Persembahan Kepada Sang Maha Guru, Seputar Hukum Bisnis (FH-UGM 2007).

Prodjodikoro, Wirjono, Asas-Asas Hukum Perdata (Penerbit Sumur 1966).

Rido, R. Ali, Badan Hukum dan Kedudukan Badan Hukum Perseroan Perkumpulan, Koperasi, Yayasan, Wakaf (Penerbit Alumni 2001). 
Salim H.S., Pengantar Hukum Perdata Tertulis (BW) (Sinar Grafika 2005).

Sastrawidjaja, Man S., Bunga Rampai Hukum Dagang (Alumni 2005).

Soemitro, Rochmat, Hukum Perseroan Terbatas, Yayasan dan Wakaf (Eresco 1993).

Subekti, Pokok-pokok Hukum Perdata (Pembimbing Masa 1996).

Sudiarja, A., Karya Lengkap Driyarkara: Esai-esai Filsafat Pemikiran yang Terlibat Penuh dalam Perjuangan Bangsa (Gramedia Pustaka Utama 2006).

Tutik, Titik Triwulan, Hukum Perdata dalam Sistem Hukum Indonesia (Prenada Media 2008).

Utrecht, E., Pengantar Dalam Hukum Indonesia (Universitas 1965). 
